\title{
Role of methylation-related genes and microRNA revealed from RNA-Seq study of FHB susceptible hexaploid wheat NIL in response to pathogen stress
}

Lalit Laxman Kharbikar ( $\sim$ lalit.kharbikar@icar.gov.in )

Indian Council of Agricultural Research https://orcid.org/0000-0002-8250-3132

Arti S. Shanware

Rashtrasant Tukadoji Maharaj Nagpur University

Shweta K. Nandanwar

Harper Adams University

Mahender S. Saharan

Indian Agricultural Research Institute

Ashish Marathe

ICAR - National Institute of Biotic Stress Management

Neeti S. Mishra

International Centre for Genetic Engineering and Biotechnology

Simon G. Edwards

Harper Adams University

\section{Research Article}

Keywords: MicroRNA, epigenetics, methylation, FHB, Fusarium graminearum, wheat

Posted Date: August 11th, 2021

DOl: https://doi.org/10.21203/rs.3.rs-795898/v1

License: (c) (i) This work is licensed under a Creative Commons Attribution 4.0 International License.

Read Full License 


\section{Abstract}

Wheat (Triticum aestivum L.), a most important crop among the cereals, accounts for over $20 \%$ of the total calories and protein available in human food. However, Fusarium graminearum, a devastating Fusarium head blight (FHB) pathogen of wheat, poses a greater threat to quality wheat grain production as it produces obnoxious mycotoxins. Presently, FHB is a minor disease in India but can cause significant yield and quality losses if rain occurs during mid-anthesis. In plants, epigenetics including DNA methylation and SRNA accumulation regulates gene expression and plays a definitive role in the adaptation to adverse environmental conditions. In a previous study response of wheat to $F$. graminearum was investigated through transcriptome analysis of lines differing for 2DL FHB resistance QTLs. However, a comprehensive analysis of methylation-related genes in response to pathogen was not performed in that study or any other studies. We re-analyzed the RNA-Seq data of said study to reveal the roles of methylation-related genes in response to F. graminearum. Sixteen methylation-related genes were down-regulated in a susceptible line, 2-2890 (pedigree of line). GO associated these genes with Lmethionine salvage from methylthioadenosine and S-adenosylmethionine and steroid biosynthesis ( $\mathrm{p}$ value 0.001 ). Co-expression analysis of this NIL with methionine S-methyl-transferase gene (MSM; TraesCS1A02G013800) resulted in 3-hydroxy-3-methyl-glutaryl coenzyme A reductase (HMGCR; TraesCS5A02G269300). HMGCR was negatively correlated (-1.00) with genes encoding pathogenesisrelated and detoxification proteins and xylanase inhibitors. GO associated these genes with methionine Smethyl transferase (p-value 0.001). Expression of HMGCR was higher (Log2 levels from 3.25 to 4.00) in pathogen inoculated compared to MSM (Log2 levels from 1.25 to 3.25) in mock-inoculated samples. 43 genes were down-regulated by miR9678. These genes are associated with responses to biotic stimulus and glucan endo-1,4-beta-glucanase in GO.

\section{Introduction:}

Wheat (Triticum spp.), an important cereal crop is a staple food for more than $40 \%$ of the world's population. It provides around $55 \%$ of the carbohydrates and $20 \%$ of food calories required for human consumption at a global level (Breiman and Graur 1995). Among the wheat-producing countries in the world, India is the second-largest producer of wheat. India is estimated to harvest 108.0 million metric tons of wheat from an area of 31.6 million hectares during 2021-22 (Anonymous, 2020). However, the most serious constraints to wheat production are diseases like blights, blue dwarf, bunts, head scab, loose smut, powdery mildew, rusts, smuts, streak mosaic and yellow dwarf (Duveiller et al. 2007; Hollandbeck et al. 2017). These diseases not only lower the production and productivity of wheat crops but also affect the quality of seeds.

Among several wheat diseases to be influenced by climate change in the near future in India is a head scab or Fusarium head blight (FHB) caused by different Fusarium spp. FHB was reported first time in England by Smith in 1884 and both bread wheat (Triticum aestivum L.) and durum wheat (Triticum durum Desf.) are devastated worldwide by this disease. It was observed that the FHB can cause a reduction in yield and quality of wheat mostly in countries where warm and wet weather conditions 
prevail (McMullen et al., 1997). Also Fusarium spp. are known to produce mycotoxins in wheat which can cause human and animal diseases upon consumption of contaminated grain (Marasas, 1984). As such the FHB outbreaks have been reported in several countries of the US, South America, Europe, Canada, Australia and Asia (McMullen et al., 1997). Therefore, the disease is considered one of the most important plant diseases at the global level during the 21 st century.

Well before its first report in England by Smith in 1884, the FHB was reported from Arunachal Pradesh in India (Roy, 1973). A year later the disease was again reported by Brahma and Singh (1985) in wheat grown on Nilgiri mountains and recently in Punjab by Saharan et al., (2020). Presently, FHB is considered of minor importance in India. However, due to the wide adoption of zero tillage by wheat growers and increased precipitation during mid-anthesis of wheat in northwestern and northeastern plain zones, the severe occurrence of disease in near future has been predicted (Saharan et al., 2020). FHB epidemics have already been reported with the adoption of conservation tillage and reduced-till systems in the Upper Midwest of the United States of America (Dill-Macky and Jones, 2000). Extensive surveys conducted from the years 2000 to 2018 have shown that the Fusarium graminearum was a predominating species in the FHB complex of wheat in India (Saharan et al., 2020). During the surveys, nearly 4000 genotypes of Indian wheat were evaluated and it was found that almost all the genotypes grown under diverse agroclimatic zones of India are susceptible to FHB. However, few moderately resistant genotypes including AKDW 2997-16, DBW 62, PBW 396, PDW 311, UAS 415, UP 2747, UP 2798, VL 926, VL 829 and WH 1021 could be identified. As very limited sources of full resistance to FHB, including the Chinese cultivars Sumai 3 and Frontana, are available the control of this disease is challenging (Kharbikar et al. 2019). This is because these sources may not be available to every wheat-growing country in the world due to weak material transfer agreements (MTA). Therefore, developing FHB resistance in the locally grown wheat cultivars is of great importance and a perfect solution for controlling this disease. However, in many crops including wheat, pathogen resistance is governed by the small RNA (sRNA)-regulated epigenetic expression of several genes in RNAi pathways (Kharbikar et al. 2019).

Epigenetic changes in response to endogenous and external stimuli play a definitive role in the adaptation of organisms to adverse environmental conditions. In plants, epigenetic mechanisms including DNA methylation and small RNAs (sRNAs) accumulation regulates gene expression (He et al. 2011). Further, sRNAs are increasingly found to regulate the epigenome through chromatin-based pathways for gene silencing (RNA-directed DNA methylation pathway), paramutation, genetic imprinting and epigenetic reprogramming (Simon and Meyers 2011). While the majority of sRNAs in plants are small interfering RNAs (siRNAs) regulating transcriptional gene silencing, microRNAs (miRNAs) play a key role in post-transcriptional gene silencing. However, the distinction between siRNAs and miRNAs is becoming blurred, as both the molecules are intimately linked in terms of their origins and modes of action. Thus, integration and analysis of sequencing data on differential gene expression, epigenetics and siRNA/miRNA-mediated regulation would reveal a comprehensive picture of the dynamics of the stressresponsive genome in generating phenotypic diversity. This could have significant implications for agriculture nevertheless the sequencing studies should focus on exploring the role of epigenetic mechanisms in environmental adaptations. 
With the advent of high throughput sequencing technologies, F. graminearum resistance in wheat has been a subject of research resulting in a deluge of transcriptomic and epigenomic data. Several genes were found to be differentially expressed in wheat under $F$. graminearum stress. Most of these genes are regulated by miRNAs in the RNAi pathways and several miRNAs have been identified and characterized in wheat (Yao et al. 2007; Han et al. 2013; Kurtoglu et al. 2013; Deng et al. 2013; Su et al. 2014; Sun et al. 2014). Few researchers have also characterized the miRNAs and their target genes in wheat in response to fungal pathogens including Fusarium (Kumar et al. 2014; Wu et al. 2014; Inal et al. 2014). However, most of these Fusarium responsive genes (FRGs) are poorly annotated and their regulatory mechanisms are not clearly understood. Further, very little is known about the miRNA-mediated epigenetic regulations of FRGs in wheat despite increasing evidence for miRNAs and DNA methylation as the important regulators of gene expression in response to biotic stresses (Agorio and Vera 2007). Recently the response of wheat to Fusarium graminearum was investigated through transcriptome analysis of lines differing for 2DL FHB resistance QTLs (Biselli et al. 2018). However, a comprehensive analysis of methylation-related genes in response to pathogen was not performed in that study or any other studies. Thus, we re-analyzed RNA-Seq data of said study to reveal roles of methylation-related genes and a miRNA in response to F. graminearum, a devastating FHB pathogen of wheat.

\section{Materials And Methods:}

\section{Selection of transcriptome datasets}

Datasets of 57 transcriptomic experiments on F. graminearum infected hexaploid wheat lines were retrieved from the National Center for Biotrchnology Information (NCBI). However, among these datasets, only one with 22 samples (Table 1) from the mRNA-Seq study could be compiled based on the same platform (Illumina) and profiling techniques. This dataset was comprised of studies on the infection of near-isogenic lines (NILs) differing for 2DL FHB resistance QTLs. 
Table 1

Selected Illumina-based mRNA-Seq datasets from transcriptomic experiments on F. graminearum infected hexaploid wheat lines retrieved from the National Center for Biotechnology Information (NCBI) for the study.

\begin{tabular}{|c|c|c|c|c|c|}
\hline Experiment & $\begin{array}{l}\text { SRA } \\
\text { accession }\end{array}$ & Cultivar & $\begin{array}{l}\text { Anatomical } \\
\text { part }\end{array}$ & Phenotype & Description \\
\hline ERX2326428 & ERS2166933 & 2618 & Leaf rachis & $\begin{array}{l}\text { Resistant } \\
\text { to FHB }\end{array}$ & $\begin{array}{l}\text { Spikelets from plants at the } \\
\text { stage of mid-anthesis were } \\
\text { both mock-inoculated } \\
\text { (water) or inoculated with } \\
\text { Fusarium graminearum } \\
\text { isolate DAOM } 180378 \text { for } 3 \\
\text { days. }\end{array}$ \\
\hline ERX2326429 & ERS2166934 & 2618 & Leaf rachis & $\begin{array}{l}\text { Resistant } \\
\text { to FHB }\end{array}$ & $\begin{array}{l}\text { Spikelets from plants at the } \\
\text { stage of mid-anthesis were } \\
\text { both mock-inoculated } \\
\text { (water) or inoculated with } \\
\text { Fusarium graminearum } \\
\text { isolate DAOM } 180378 \text { for } 3 \\
\text { days. }\end{array}$ \\
\hline ERX2326430 & ERS2166935 & 2618 & Leaf rachis & $\begin{array}{l}\text { Resistant } \\
\text { to FHB }\end{array}$ & $\begin{array}{l}\text { Spikelets from plants at the } \\
\text { stage of mid-anthesis were } \\
\text { both mock-inoculated } \\
\text { (water) or inoculated with } \\
\text { Fusarium graminearum } \\
\text { isolate DAOM } 180378 \text { for } 3 \\
\text { days. }\end{array}$ \\
\hline ERX2326431 & ERS2166936 & 2618 & Spikelet & $\begin{array}{l}\text { Resistant } \\
\text { to FHB }\end{array}$ & $\begin{array}{l}\text { Spikelets from plants at the } \\
\text { stage of mid-anthesis were } \\
\text { both mock-inoculated } \\
\text { (water) or inoculated with } \\
\text { Fusarium graminearum } \\
\text { isolate DAOM } 180378 \text { for } 3 \\
\text { days. }\end{array}$ \\
\hline ERX2326432 & ERS2166937 & 2618 & Spikelet & $\begin{array}{l}\text { Resistant } \\
\text { to FHB }\end{array}$ & $\begin{array}{l}\text { Spikelets from plants at the } \\
\text { stage of mid-anthesis were } \\
\text { both mock-inoculated } \\
\text { (water) or inoculated with } \\
\text { Fusarium graminearum } \\
\text { isolate DAOM } 180378 \text { for } 3 \\
\text { days. }\end{array}$ \\
\hline ERX2326433 & ERS2166938 & 2618 & Spikelet & $\begin{array}{l}\text { Resistant } \\
\text { to FHB }\end{array}$ & $\begin{array}{l}\text { Spikelets from plants at the } \\
\text { stage of mid-anthesis were } \\
\text { both mock-inoculated } \\
\text { (water) or inoculated with } \\
\text { Fusarium graminearum } \\
\text { isolate DAOM } 180378 \text { for } 3 \\
\text { days. }\end{array}$ \\
\hline
\end{tabular}




\begin{tabular}{|c|c|c|c|c|c|}
\hline Experiment & $\begin{array}{l}\text { SRA } \\
\text { accession }\end{array}$ & Cultivar & $\begin{array}{l}\text { Anatomical } \\
\text { part }\end{array}$ & Phenotype & Description \\
\hline ERX2326434 & ERS2166939 & 2618 & Leaf rachis & $\begin{array}{l}\text { Resistant } \\
\text { to FHB }\end{array}$ & $\begin{array}{l}\text { Spikelets from plants at the } \\
\text { stage of mid-anthesis were } \\
\text { both mock-inoculated } \\
\text { (water) or inoculated with } \\
\text { Fusarium graminearum } \\
\text { isolate DAOM } 180378 \text { for } 3 \\
\text { days. }\end{array}$ \\
\hline ERX2326435 & ERS2166940 & 2618 & Leaf rachis & $\begin{array}{l}\text { Resistant } \\
\text { to FHB }\end{array}$ & $\begin{array}{l}\text { Spikelets from plants at the } \\
\text { stage of mid-anthesis were } \\
\text { both mock-inoculated } \\
\text { (water) or inoculated with } \\
\text { Fusarium graminearum } \\
\text { isolate DAOM } 180378 \text { for } 3 \\
\text { days. }\end{array}$ \\
\hline ERX2326436 & ERS2166941 & 2618 & Spikelet & $\begin{array}{l}\text { Resistant } \\
\text { to FHB }\end{array}$ & $\begin{array}{l}\text { Spikelets from plants at the } \\
\text { stage of mid-anthesis were } \\
\text { both mock-inoculated } \\
\text { (water) or inoculated with } \\
\text { Fusarium graminearum } \\
\text { isolate DAOM } 180378 \text { for } 3 \\
\text { days. }\end{array}$ \\
\hline ERX2326437 & ERS2166942 & 2618 & Spikelet & $\begin{array}{l}\text { Resistant } \\
\text { to FHB }\end{array}$ & $\begin{array}{l}\text { Spikelets from plants at the } \\
\text { stage of mid-anthesis were } \\
\text { both mock-inoculated } \\
\text { (water) or inoculated with } \\
\text { Fusarium graminearum } \\
\text { isolate DAOM } 180378 \text { for } 3 \\
\text { days. }\end{array}$ \\
\hline ERX2326438 & ERS2166943 & 2618 & Spikelet & $\begin{array}{l}\text { Resistant } \\
\text { to FHB }\end{array}$ & $\begin{array}{l}\text { Spikelets from plants at the } \\
\text { stage of mid-anthesis were } \\
\text { both mock-inoculated } \\
\text { (water) or inoculated with } \\
\text { Fusarium graminearum } \\
\text { isolate DAOM } 180378 \text { for } 3 \\
\text { days. }\end{array}$ \\
\hline ERX2326439 & ERS2166944 & 2890 & Leaf rachis & $\begin{array}{l}\text { Susceptible } \\
\text { to FHB }\end{array}$ & $\begin{array}{l}\text { Spikelets from plants at the } \\
\text { stage of mid-anthesis were } \\
\text { both mock-inoculated } \\
\text { (water) or inoculated with } \\
\text { Fusarium graminearum } \\
\text { isolate DAOM } 180378 \text { for } 3 \\
\text { days. }\end{array}$ \\
\hline ERX2326440 & ERS2166945 & 2890 & Leaf rachis & $\begin{array}{l}\text { Susceptible } \\
\text { to FHB }\end{array}$ & $\begin{array}{l}\text { Spikelets from plants at the } \\
\text { stage of mid-anthesis were } \\
\text { both mock-inoculated } \\
\text { (water) or inoculated with } \\
\text { Fusarium graminearum } \\
\text { isolate DAOM } 180378 \text { for } 3 \\
\text { days. }\end{array}$ \\
\hline
\end{tabular}




\begin{tabular}{|c|c|c|c|c|c|}
\hline Experiment & $\begin{array}{l}\text { SRA } \\
\text { accession }\end{array}$ & Cultivar & $\begin{array}{l}\text { Anatomical } \\
\text { part }\end{array}$ & Phenotype & Description \\
\hline ERX2326441 & ERS2166946 & 2890 & Spikelet & $\begin{array}{l}\text { Susceptible } \\
\text { to FHB }\end{array}$ & $\begin{array}{l}\text { Spikelets from plants at the } \\
\text { stage of mid-anthesis were } \\
\text { both mock-inoculated } \\
\text { (water) or inoculated with } \\
\text { Fusarium graminearum } \\
\text { isolate DAOM } 180378 \text { for } 3 \\
\text { days. }\end{array}$ \\
\hline ERX2326442 & ERS2166947 & 2890 & Spikelet & $\begin{array}{l}\text { Susceptible } \\
\text { to FHB }\end{array}$ & $\begin{array}{l}\text { Spikelets from plants at the } \\
\text { stage of mid-anthesis were } \\
\text { both mock-inoculated } \\
\text { (water) or inoculated with } \\
\text { Fusarium graminearum } \\
\text { isolate DAOM } 180378 \text { for } 3 \\
\text { days. }\end{array}$ \\
\hline ERX2326443 & ERS2166948 & 2890 & Spikelet & $\begin{array}{l}\text { Susceptible } \\
\text { to FHB }\end{array}$ & $\begin{array}{l}\text { Spikelets from plants at the } \\
\text { stage of mid-anthesis were } \\
\text { both mock-inoculated } \\
\text { (water) or inoculated with } \\
\text { Fusarium graminearum } \\
\text { isolate DAOM } 180378 \text { for } 3 \\
\text { days. }\end{array}$ \\
\hline ERX2326444 & ERS2166949 & 2890 & Spikelet & $\begin{array}{l}\text { Susceptible } \\
\text { to FHB }\end{array}$ & $\begin{array}{l}\text { Spikelets from plants at the } \\
\text { stage of mid-anthesis were } \\
\text { both mock-inoculated } \\
\text { (water) or inoculated with } \\
\text { Fusarium graminearum } \\
\text { isolate DAOM } 180378 \text { for } 3 \\
\text { days. }\end{array}$ \\
\hline ERX2326445 & ERS2166950 & 2890 & Spikelet & $\begin{array}{l}\text { Susceptible } \\
\text { to FHB }\end{array}$ & $\begin{array}{l}\text { Spikelets from plants at the } \\
\text { stage of mid-anthesis were } \\
\text { both mock-inoculated } \\
\text { (water) or inoculated with } \\
\text { Fusarium graminearum } \\
\text { isolate DAOM } 180378 \text { for } 3 \\
\text { days. }\end{array}$ \\
\hline ERX2326446 & ERS2166951 & 2890 & Spikelet & $\begin{array}{l}\text { Susceptible } \\
\text { to FHB }\end{array}$ & $\begin{array}{l}\text { Spikelets from plants at the } \\
\text { stage of mid-anthesis were } \\
\text { both mock-inoculated } \\
\text { (water) or inoculated with } \\
\text { Fusarium graminearum } \\
\text { isolate DAOM } 180378 \text { for } 3 \\
\text { days. }\end{array}$ \\
\hline ERX2326447 & ERS2166952 & 2890 & Leaf rachis & $\begin{array}{l}\text { Susceptible } \\
\text { to FHB }\end{array}$ & $\begin{array}{l}\text { Spikelets from plants at the } \\
\text { stage of mid-anthesis were } \\
\text { both mock-inoculated } \\
\text { (water) or inoculated with } \\
\text { Fusarium graminearum } \\
\text { isolate DAOM } 180378 \text { for } 3 \\
\text { days. }\end{array}$ \\
\hline
\end{tabular}




\begin{tabular}{|c|c|c|c|c|c|}
\hline Experiment & $\begin{array}{l}\text { SRA } \\
\text { accession }\end{array}$ & Cultivar & $\begin{array}{l}\text { Anatomical } \\
\text { part }\end{array}$ & Phenotype & Description \\
\hline ERX2326448 & ERS2166953 & 2890 & Leaf rachis & $\begin{array}{l}\text { Susceptible } \\
\text { to FHB }\end{array}$ & $\begin{array}{l}\text { Spikelets from plants at the } \\
\text { stage of mid-anthesis were } \\
\text { both mock-inoculated } \\
\text { (water) or inoculated with } \\
\text { Fusarium graminearum } \\
\text { isolate DAOM } 180378 \text { for } 3 \\
\text { days. }\end{array}$ \\
\hline ERX2326449 & ERS2166954 & 2890 & Leaf rachis & $\begin{array}{l}\text { Susceptible } \\
\text { to FHB }\end{array}$ & $\begin{array}{l}\text { Spikelets from plants at the } \\
\text { stage of mid-anthesis were } \\
\text { both mock-inoculated } \\
\text { (water) or inoculated with } \\
\text { Fusarium graminearum } \\
\text { isolate DAOM } 180378 \text { for } 3 \\
\text { days. }\end{array}$ \\
\hline
\end{tabular}

\section{Selection of methylation-related genes}

A total of 218 methylation-related genes including 100 probesets in wheat were retrieved from the Ensemble Gene database using the term "methyl".

\section{Methylation-related gene search from transcriptome dataset}

The methylation-related genes which were down-regulated in susceptible versus up-regulated in resistant wheat lines after pathogen inoculation were searched using the Similarity Search tool of Genvestigator (Hruz et al. 2008). Sixteen genes down-regulated in susceptible line 2890 were retrieved after hierarchical clustering based on the Euclidean distance.

\section{Differential co-expression analysis}

Co-expression analysis of methylation-related genes in 22 samples from the selected dataset was performed using TraesCS1A02G013800 as a lead gene. The analysis was tried with all the 218 methylation-related genes.

\section{Gene ontology enrichment analysis of the selected genes}

Gene set enrichment analysis was performed on all the negatively correlated downregulating genes in susceptible line 2890 . The agriGo platform was used for finding the enriched gene ontology (GO) terms (Tian et al. 2017). The background reference gene was TraesCS1A02G013800 with a correlation coefficient of about -1.00. A gene-GO term association network was constructed using Gephi and the visualization layout was modified according to the network parameter, Degree.

\section{2 - Gene Plot}

A 2 - gene plot was constructed for all the negatively correlated genes considering the samples and treatment status. 


\section{Small RNA analysis}

Eight experiments from 4 species including Arabidopsis thaliana, Oryza sativa, Zea mays and Triticum aestivum available in ENA were selected. However, miRNAs from $T$. aestivum could only be analyzed based on the same platform (Illumina) and profiling techniques. Six sRNA genes of T. aestivum were also retrieved from Ensemble using the term 'small RNA'. In silico analyses for condition search, gene search and similarity search were performed on these data to study the effects of sRNAs on methylation-related genes.

\section{Results And Discussion:}

\section{Down- and up-regulation of methylation-related genes}

In the present study, hierarchical clustering based on the Euclidean distance showed that 16 methylationrelated genes were down-regulated in a susceptible line, 2-2890 (Fig. 1). Corresponding genes were upregulated in a resistant line 2-2618 upon $F$. graminearum inoculation.

Genomic DNA methylation levels have been shown to change in plants to adapt to the stresses including pathogen infections (Viggiano and de Pinto 2017). By this epigenetic mechanism, stable alteration in gene expression without changes in the underlying DNA sequence occurs that results in normal plant development (Verhoeven et al. 2010; Zhang et al. 2010; Ganguly et al. 2017; Hewezi 2018).

In the present study since a susceptible line, 2-2890 could not adapt to the $F$. graminearum stress 16 methylation-related genes were seen to be down-regulated. This indicates that genomic DNA methylation did not occur in a susceptible line and hence surrendered to the pathogen infection resulting in a rapid progression of the FHB disease. However, in a resistant line, 2-2618 genomic DNA methylation did occur since the methylation-related genes were up-regulated checking the spread of the FHB disease.

Gene ontology (GO) analysis associated these methylation-related genes with L-methionine salvage from methylthioadenosine and S-adenosylmethionine and steroid biosynthesis (p-value 0.001) (Fig. 2).

In the present study GO analysis of methylation-related genes suggested that methylation of the plant DNA might activate the steroid biosynthesis pathway in a resistant line. This plausibly helped protect the wheat plants from infection upon $F$. graminearum inoculation. In plants, various steroid products such as steroid glycoalkaloids and sesquiterpenoid phytoalexins, sterols, brassinosteroids and cytokinins, farnesyl and geranyl groups, dolichols and ubiquinone have been reported to require for defence-related functions including membrane biogenesis, control of growth and development, protein prenylation, protein glycosylation and respiration (Stermer et al. 1994; Chappell 1995).

\section{Co-expression analysis of methylation-related genes}

Co-expression analysis of methylation-related genes in FHB S 2-2890 NIL with methionine S-methyltransferase gene (MSM; TraesCS1A02G013800) resulted in 3-hydroxy-3-methyl-glutaryl coenzyme A 
reductase (HMGCR; TraesCS5A02G269300) (Fig. 3).

The HMGCR catalyzes the first essential step of a mevalonate (MVA) pathway for isoprenoid biosynthesis (Caelles et al. 1989). This pathway provides precursors for a wide variety of isoprenoid products that are required for very diverse functions, including defence against pathogen attacks. In the present study, a negative correlation (-0.82) between methylation-related genes and a gene encoding MSM in FHB S 2-2890 NIL was found (Fig. 3). This indicates that although the expression levels of methylation-related genes might have increased initially upon pathogen infection the MSM levels could have been decreased. This is possible because of a certain counter-defence mechanism of pathogen against MSM, leading to the suppression of MSM encoding gene during the further infection process. As a result, a lower level of HMGCR could have been produced in a susceptible line and hence, less isoprenoid biosynthesis. Varying levels of HMGCR isoforms (from higher levels of HMGR1S to 10 times lower levels of HMGR1L and HMGR2) in inflorescences, seedlings and roots of Arabidopsis thaliana in response to a variety of stress conditions have been reported previously (Enjuto et al. 1994; Enjuto et al. 1995; Lumbreras et al. 1995). Plant HMGCR has also been reported to be modulated by myriad endogenous signals and external stimuli including pathogen attack (Stermer et al. 1994; RodríguezConcepción et al. 2013).

Further, the HMGCR was found to be negatively correlated (-1.00) to genes encoding pathogenesis-related and detoxification proteins and xylanase inhibitors in the present study (Fig. 4). This means that as the level of HMGCR decreases the levels of pathogenesis-related and detoxification proteins and xylanase inhibitors increases in the pathogen-infected plants. This suggests that a decrease in HMGCR level is needed for a blockage of certain biosynthetic routes to redirect photoassimilates and energy for the urgent synthesis of adaptive compounds. However, probably due to the less efficient recognition or signal response pathways the susceptible plants may not take advantage of this defence mechanism. The changes in HMGR levels may occur at different rates, depending on the plant system and the type and severity of the stress condition as suggested previously (Leivar et al. 2011). These results suggest that the synthesis of HMGCR is independent of the synthesis of adaptive compounds such as pathogenesisrelated and detoxification proteins and xylanase inhibitors. We speculate that the two different pathways for synthesis of HMGCR and adaptive compounds respectively might get activated sequentially upon pathogen infection. However, plants use HMGCR modifications to expand their adaptations against stresses for maximizing energy consumption efficiency and resistance responses when needed.

GO analysis of the negatively correlated methylation-related genes

To study the regulation of DNA methylation in plants in response to pathogen infection the gene set enrichment analysis was carried out and the results are displayed on the Venn diagram (Fig. 5). GO analysis associated the genes, encoding pathogenesis-related and detoxification proteins as well as xylanase inhibitors, with methionine S-methyl transferase activity (p-value 0.001$)$. The transferase activity and methionine S-methyl transferase activity shared the most co-expressing genes $(3401+4+1=3406)$, indicating similar functions between these two gene groups. 
Results of the GO analysis suggest that the methyltransferases regulate the expression of defence-related genes including PR proteins, detoxification proteins and xylanase inhibitors. Recently, DNA methylations were shown to have a significant role in plant resistance responses by controlling the expression level of the defence genes (Geng et al. 2019). The expression of PR2 genes was activated in methylationdefective mutants of a diploid wheat species obtained through silencing of a methylation-related gene DRM2. DNA hypomethylation caused due to infection of an obligate biotrophic fungus Blumeria graminis f. sp. Tritici was thought to upregulate some defence-related genes in that study. Similarly, methylationdefective mutants of Arabidopsis were found to be more susceptible than the wildtype to Botrytis cinerea and Plectosphaerella cucumerina (López et al. 2011). Previously several genes encoding methyltransferases have been reported to confer resistance in plants against various pathogens (He and Dixon 2000; Seo et al. 2001; Xu et al. 2006; Berr et al. 2010; Yang et al. 2017; Salvador-Guirao et al. 2018).

2 - Gene plot analysis of negatively correlated genes

Expression levels of 3-hydroxy-3-methyl-glutaryl coenzyme A reductase (HMGCR) were higher (Log2 levels from 3.25 to 4.00 ) in pathogen inoculated compared to methionine S-methyl-transferase (MSM) (Log2 levels from 1.25 to 3.25) in mock-inoculated FHB S line, 2-2890.

HMGCR was also reported in cotton and potato following inoculation of Verticillium dahliae and Phytophthora infestans, respectively in previous studies (Joost et al. 1995; Yoshioka et al. 1996). Expression of HMGCR in pathogen inoculated susceptible lines in the present study indicates its specialized role in plants under stress conditions including pathogen infection. Whereas, the expression of MSM in the mock-inoculated susceptible line indicates its generalized role in the plant's normal DNA methylation processes. Continuous expression of HMGCR has also been reported in a susceptible cotton cultivar by Joost et al. 1995. As HMGCR is required for the biosynthesis of isoprenoids (Caelles et al. 1989 ) its increased levels may lead to a burst of isoprenoids, halting the initial spread of a pathogen. However, due to the phytotoxic effects of excessive isoprenoids, the susceptible plants may succumb to further infection processes as their recognition or signal response pathways are weak.

Effects of miRNAs on methylation-related genes

Forty-three methylation-related genes were down-regulated by a miRNA miR9678 (Fig. 7a). These genes were enriched in the $\mathrm{GO}$ categories of responses to biotic stimulus and glucan endo-1,4-beta-glucanase among others (Fig. 7b).

Previously miRNAs have been found to target the methyltransferases and therefore reported as the negative regulators of DNA methylation (Das et al. 2010). The authors affirmed that a miR153 targets the methyltransferase DNMT1 and downregulates the DNA methylation of DNMTt targeted genes. From our results, we speculate that the miR9678:methyltransferase-RNA duplexes may lead to the down-regulation of methyltransferase genes. This is evident from a previous study conducted by Khraiwesh et al. (2010) on miR166-target interaction in moss (Physcomitrella patens). The authors revealed the involvement of miRNA:target-RNA duplexes through interactions of miR166 with its target genes, PpC3HDZIP1 and 
PpHB10, respectively in a $\triangle \mathrm{PpDCL} 1 \mathrm{~b}$ mutant. Although this is not direct evidence for miR9678 this miRNA has been shown to modulate abscisic acid/gibberellin (ABA/GA) signalling in wheat by targeting a long noncoding RNA (WSGAR) (Guo et al. 2018). Overexpression of this miRNA in transgenic wheat lines reduced the GA content and affected the expression of WSGAR genes. However, there are possibilities that miR9678 might target genes other than WSGAR and the addition of genome sequences to available wheat genomic resources may support this hypothesis. To this end, the downregulation of methylation-related genes in the present study might result from the suppression of certain miRNA9678 target genes including the methyltransferases. Guo et al. (2018) also proposed different genes, such as aamylase and genes required for the production of specific GAs (i.e., TaCPS, TaKO, and TaKS), as the targets of miR9678.

Guo et al. (2018) proved the role of the ABA-miR9678-GA mechanism in wheat seed germination; however, the role of this mechanism in plant defence can be ascertained from the present study. Some plant pathogenic fungi including F. graminearum have been reported to produce ABA via an MVA biosynthetic pathway (Siewers et al. 2004; Siewers et al. 2006; Qi et al. 2016). ABA produced by F. graminearum seems to suppress the wheat immune responses as reported earlier (Lievens et al. 2017). Upon F. graminearum infection ABA signalling regulators in wheat like TaVP1/TaABF/TaABI5 may bind to the promoter of miR9678 and activate its expression. In a previous study miR9678 has been shown to upregulate upon ABA treatment (Guo et al. 2018). Once the expression of miR9678 increases upon F. graminearum infection the miR9678:methyltransferase-RNA duplexes may lead to downregulation of methyltransferase genes. Due to the downregulation of methyltransferase genes, methylation of the genes responsive to biotic stimulus including glucan endo-1,4-beta-glucanase may not occur. This may lead to the susceptibility of a host plant to the invading pathogen. Previously ABA has been shown to increase the susceptibility of Arabidopsis to F. oxysporum (Anderson et al. 2004; Trusov et al. 2009). Similarly, exogenous applications of ABA has been shown to increase the susceptibility of rice and barley to Magnaporthe grisea and M. oryzae, respectively (Koga et al. 2004; Ulferts et al. 2015).

Like plants GA, a phytohormone can also be produced by many plant pathogens including species of Fusarium (Yabuta et al. 1950; MacMillan 2001). However, exogenous application of this phytohormone on plants has been shown to induce defence-related genes in plants in response to pathogens (Casacuberta et al. 1992). Subsequent studies have also reported that GA enhances the resistance of plants to diseases caused by ascomycetes fungi (Eshel et al. 2002; Tanaka et al. 2006). Although the functioning of GA has not been studied during plant-pathogen interactions we speculate that the resistant plants produce higher levels of GA than ABA upon pathogen infection. These higher levels of GA may misregulate the expression of pathogen genes that are involved in early to later-stage infection events. Repression of nitrogen metabolic genes of $F$. graminearum upon GA application has been reported to reduce bioenergetic resources and redox regulation during early-stage infection (Buhrow et al. 2016). The authors also suggested that GA may regulate gene expression in $F$. graminearum during later-stage infection events. 
In the present study, we provide theoretical evidence about the ABA-miR9678-GA mechanism that affect defence responses in plants against invading pathogens (Fig. 8a, b). Once F. graminearum infects both susceptible and resistant wheat plants it produces higher levels of ABA to facilitate its invasion.

Following this, ABA signalling regulators in susceptible wheat plants binds to a promoter of miR9678 and increases its expression; however, in resistant wheat plants levels of GA increases. Once the expression of miR9678 increases the miRNA downregulates its target methyltransferase genes in susceptible plants. Whereas, in resistant plants, the increased levels of GA misregulate the expression of pathogen genes. In susceptible plants, methylation of genes responsive to biotic stimulus including glucan endo-1,4-betaglucanase may not occur due to downregulated methyltransferase genes. This may lead to the progression of pathogen infection in susceptible plants. In the case of resistant plants, misregulation of the pathogen's metabolic genes required for the establishment and progression of infection events may result in enhanced resistance.

\section{Conclusion:}

The results of this study support previous findings that pathogen infection causes DNA methylation and increases the accumulation of miRNAs. In the present study since a susceptible line, 2-2890 could not adapt to the $F$. graminearum stress 16 methylation-related genes were seen to be down-regulated. GO analysis associated these methylation-related genes with L-methionine salvage from methylthioadenosine and S-adenosylmethionine and steroid biosynthesis. This suggests that methylation of the plant DNA might activate the steroid biosynthesis pathway which is vital for imparting pathogen resistance in plants. However, a negative correlation between methylation-related genes and a gene encoding MSM in a susceptible line was found in the present study. This indicates that although the expression levels of methylation-related genes might have increased initially upon pathogen infection the MSM levels could have been decreased. This is possible because of a certain counter-defence mechanism of pathogen against MSM, leading to the suppression of MSM encoding gene during the further infection process. As a result, a lower level of HMGCR could have been produced in a susceptible line and hence, less steroid biosynthesis. Further, GO analysis associated the genes, encoding pathogenesis-related and detoxification proteins as well as xylanase inhibitors, with methionine S-methyl transferase activity. This suggests that the methyltransferases regulate the expression of defence-related genes including PR proteins, detoxification proteins and xylanase inhibitors.

From our results, we speculate that the miR9678:methyltransferase-RNA duplexes may lead to the downregulation of methyltransferase genes. Although direct evidence for the involvement of miR9678 could not be provided this miRNA has been shown to modulate ABA/GA signalling in wheat in a previous study (Guo et al. 2018). Hence, the downregulation of methylation-related genes in the present study might result from the suppression of certain miRNA9678 target genes including the methyltransferases. Increased expression of miR9678 upon $F$. graminearum infection may lead to the miR9678:methyltransferase-RNA duplexes and ultimately downregulate the methyltransferase genes. As a result, methylation of the genes responsive to biotic stimulus including glucan endo-1,4-beta-glucanase may not occur leading to the susceptibility of a host plant to the invading pathogen. 
In the present study, we provide theoretical evidence about the ABA-miR9678-GA mechanism that affect defence responses in plants against invading pathogens. In susceptible plants binding of ABA signalling regulators to a promoter of miR9678 increases its expression and downregulates its target methyltransferase genes. This results in the nonmethylation of defence genes. However, in resistant plants increased levels of GA misregulate the expression of pathogen's metabolic genes resulting in enhanced disease resistance. If this model of the ABA-miR9678-GA defence mechanism could be proved experimentally, alleles associated with desirable levels of expression of miR9678 can be used in markerassisted selection to fine-tune resistance breeding. Further, an observation that increased expression of miR9678 increases susceptibility to FHB suggests that artificial regulation of this miRNA could be used to modulate defence response in wheat. In addition, the regulated expression of miR9678 may be useful in preventing pleiotropic effects reported earlier to negatively affect yield and quality traits due to its overexpression (Guo et al. 2018). However, this study warrants further investigations on the involvement of miR9678 in the plant's defence mechanism against invading pathogens.

\section{Declarations}

\section{Author contributions}

All authors contributed to the study conception and design. Material preparation, data collection and analysis were performed by Lalit L. Kharbikar, Shweta K. Nandanwar and Ashish Marathe. The first draft of the manuscript was written by Lalit L. Kharbikar, Arti S. Shanware and Mahender S. Saharan. Neeti S. Mishra and Simon G. Edwards commented on previous versions of the manuscript. All authors read and approved the final manuscript.

\section{Funding}

The first author received funding from Indian National Science Academy, New Delhi, India under INSA Visiting Scientist Programme 2019 No. INSA/SP/VSP-59/2019-20/ for the research leading to these results. This work was supported by the International Centre for Genetic Engineering and Biotechnology, New Delhi, India.

\section{Conflicts of Interest}

The authors have no conflicts of interest to declare that are relevant to the content of this article.

\section{Data availability}

The datasets analysed during the current study are available in the National Center for Biotrchnology Information (NCBI) repository, https://www.ncbi.nlm.nih.gov/Traces/study/?

query_key=4\&WebEnv=MCID_610cccf1abee6b58f26ca234\&o=acc_s\%3Aa

\section{References}


1. Agorio A, Vera P (2007) ARGONAUTE4 is required for resistance to Pseudomonas syringae in Arabidopsis. Plant Cell 19:3778-3790. https://doi.org/10.1105/tpc.107.054494

2. Anderson JP, Badruzsaufari E, Schenk PM, Manners JM, Desmond OJ, Ehlert C, Maclean DJ, Ebert PR, Kazan K (2004) Antagonistic interaction between abscisic acid and jasmonate-ethylene signaling pathways modulates defense gene expression and disease resistance in arabidopsis. Plant Cell 16:3460-3479. https://doi.org/10.1105/tpc.104.025833

3. Anonymous (2020).United States Department of Agriculture: World Agricultural Production. https://www.usda.gov/oce/commodity/wasde/

4. Berr A, McCallum EJ, Alioua A, Heintz D, Heitz T, Shen WH (2010) Arabidopsis histone methyltransferase SET DOMAIN GROUP8 mediates induction of the jasmonate/ethylene pathway genes in plant defense response to necrotrophic fungi. Plant Physiol 154:1403-1414. https://doi.org/10.1104/pp.110.161497

5. Biselli C, Bagnaresi P, Faccioli P, Hu X, Balcerzak M, Mattera MG, ... Valè G (2018) Comparative transcriptome profiles of near-isogenic hexaploid wheat lines differing for effective alleles at the 2DL FHB resistance QTL. Frontiers in plant science 9:37. https://doi.org/10.3389/fpls.2018.00037

6. Brahma RN, Singh SD (1985) Occurrence of scab of wheat in the Nilgiris hills. Curr Sci 54(22):11841185

7. Breiman A, Graur D (1995) Wheat evolution. Israel Journal of Plant Sciences 43(2):85-98

8. Buhrow LM, Cram D, Tulpan D, Foroud NA, Loewen MC (2016) Exogenous abscisic acid and gibberellic acid elicit opposing effects on Fusarium graminearum infection in wheat. Phytopathology 106:986-996. https://doi.org/10.1094/PHYT0-01-16-0033-R

9. Caelles C, Ferrer A, Balcells L, Hegardt FG, Boronat A (1989) Isolation and structural characterization of a cDNA encoding Arabidopsis thaliana 3-hydroxy-3-methylglutaryl coenzyme A reductase. Plant Mol Biol 13:627-638. https://doi.org/10.1007/BF00016018

10. Casacuberta JM, Raventós D, Puigdoménech P, San Segundo B (1992) Expression of the gene encoding the PR-like protein PRms in germinating maize embryos. MGG Mol Gen Genet 234:97-104. https://doi.org/10.1007/BF00272350

11. Chappell J (1995) The biochemistry and molecular biology of isoprenoid metabolism. Plant Physiol 107:1-6. https://doi.org/10.1104/pp.107.1.1

12. Das S, Foley N, Bryan K, Watters KM, Bray I, Murphy DM, Buckley PG, Stallings RL (2010) MicroRNA mediates DNA demethylation events triggered by retinoic acid during neuroblastoma cell differentiation. Cancer Res 70:7874-7881. https://doi.org/10.1158/0008-5472.CAN-10-1534

13. Deng P, Nie X, Wang L, Cui L, Liu P, Tong W, Biradar SS, Edwards D, Berkman P, Šimková H, Doležel J, Luo M, You F, Batley J, Fleury D, Appels R, Weining S (2013) Computational Identification and Comparative Analysis of miRNAs in Wheat Group 7 Chromosomes. Plant Mol Biol Report 32:487500. https://doi.org/10.1007/s11105-013-0669-x

14. Dill-Macky R, Jones RK (2000) The effect of previous crop residues and tillage on Fusarium head blight of wheat. Plant Dis 84(1):71-76 
15. Duveiller E, Singh RP, Nicol JM (2007) The challenges of maintaining wheat productivity: pests, diseases and potential epidemics. Euphytica 157(3):417-430

16. Enjuto M, Balcells L, Campos N, Caelles C, Arró M, Boronat A (1994) Arabidopsis thaliana contains two differentially expressed 3-hydroxy-3-methylglutaryl-CoA reductase genes, which encode microsomal forms of the enzyme. Proc Natl Acad Sci U S A 91:927-931. https://doi.org/10.1073/pnas.91.3.927

17. Enjuto M, Lumbreras V, Marin C, Boronat A (1995) Expression of the Arabidopsis HMG2 gene, encoding 3-hydroxy-3-methylglutaryl coenzyme A reductase, is restricted to meristematic and floral tissues. Plant Cell 7:517-527. https://doi.org/10.1105/tpc.7.5.517

18. Eshel D, Lichter A, Dinoor A, Prusky D (2002) Characterization of Alternaria alternata glucanase genes expressed during infection of resistant and susceptible persimmon fruits. Mol Plant Pathol 3:347-358. https://doi.org/10.1046/j.1364-3703.2002.00127.x

19. Ganguly DR, Crisp PA, Eichten SR, Pogson BJ (2017) The arabidopsis DNA methylome is stable under transgenerational drought stress. Plant Physiol 175:1893-1912. https://doi.org/10.1104/pp.17.00744

20. Geng S, Kong X, Song G, Jia M, Guan J, Wang F, Qin Z, Wu L, Lan X, Li A, Mao L (2019) DNA methylation dynamics during the interaction of wheat progenitor Aegilops tauschii with the obligate biotrophic fungus Blumeria graminis f. sp. tritici. New Phytol 221:1023-1035. https://doi.org/10.1111/nph.15432

21. Guo G, Liu X, Sun F, Cao J, Huo N, Wuda B, Xin M, Hu Z, Du J, Xia R, Rossi V, Peng H, Ni Z, Sun Q, Yao $Y(2018)$ Wheat miR9678 affects seed germination by generating phased siRNAs and modulating abscisic acid/gibberellin signaling. Plant Cell 30:796-814. https://doi.org/10.1105/tpc.17.00842

22. Han J, Kong ML, Xie H, Sun QP, Nan ZJ, Zhang QZ, Pan JB (2013) Identification of miRNAs and their targets in wheat (Triticum aestivum L.) by EST analysis. Genet Mol Res 12:3793-3805

23. He XZ, Dixon RA (2000) Genetic manipulation of isoflavone 7-0-methyltransferase enhances biosynthesis of 4'-0-methylated isoflavonoid phytoalexins and disease resistance in alfalfa. Plant Cell 12:1689-1702. https://doi.org/10.1105/tpc.12.9.1689

24. He XJ, Chen T, Zhu JK (2011) Regulation and function of DNA methylation in plants and animals. Cell Res 21:442-465

25. Hewezi T (2018) Editorial: epigenetic regulation of plant development and stress responses. Plant Cell Rep. 37

26. Hollandbeck GF, DeWolf E, Todd T (2017) Kansas Cooperative Plant Disease Survey Report Preliminary 2017 Kansas Wheat Disease Loss Estimates, pp 1-6

27. Hruz T, Laule O, Szabo G, Wessendorp F, Bleuler S, Oertle L, Widmayer P, Gruissem W, Zimmermann P (2008) Genevestigator V3: A Reference Expression Database for the Meta-Analysis of Transcriptomes. Adv Bioinformatics 2008:1-5. https://doi.org/10.1155/2008/420747

28. Inal B, Türktaş M, Eren H, Ilhan E, Okay S, Atak M, Erayman M, Unver T (2014) Genome-wide fungal stress responsive miRNA expression in wheat. Planta 240:1287-1298. 
https://doi.org/10.1007/s00425-014-2153-8

29. Joost O, Bianchini G, Bell AA, Benedict CR, Magill CW (1995) Differential induction of 3-hydroxy-3methylglutaryl CoA reductase in two cotton species following inoculation with Verticillium. Mol PlantMicrobe Interact 8:880-885. https://doi.org/10.1094/MPMI-8-0880

30. Kharbikar LL, Shanware AS, Saharan MS, Nandanwar SK, Sivalingam PN, Gurjar MS, Aggarwal R (2019) Fusarium graminearum microRNA-like RNAs and their interactions with wheat genome: a much-needed study. Indian Phytopathol 72:565-573. https://doi.org/10.1007/s42360-019-00139-4

31. Khraiwesh B, Arif MA, Seumel GI, Ossowski S, Weigel D, Reski R, Frank W (2010) Transcriptional Control of Gene Expression by MicroRNAs. Cell 140:111-122.

https://doi.org/10.1016/j.cell.2009.12.023

32. Koga H, Dohi K, Mori M (2004) Abscisic acid and low temperatures suppress the whole plant-specific resistance reaction of rice plants to the infection of Magnaporthe grisea. Physiol Mol Plant Pathol 65:3-9. https://doi.org/10.1016/j.pmpp.2004.11.002

33. Kumar D, Singh D, Kanodia P, Prabhu KV, Kumar M, Mukhopadhyay K (2014) Discovery of Novel Leaf Rust Responsive microRNAs in Wheat and Prediction of Their Target Genes. J Nucleic Acids 2014

34. Kurtoglu KY, Kantar M, Lucas SJ, Budak H (2013) Unique and conserved microRNAs in wheat chromosome 5D revealed by next-generation sequencing. PLoS One 8:e69801. https://doi.org/10.1371/journal.pone.0069801

35. Leivar P, Antolín-Llovera M, Ferrero S, Closa M, Arró M, Ferrer A, Boronat A, Campos N (2011) Multilevel control of Arabidopsis 3-hydroxy-3-methylglutaryl coenzyme a reductase by protein phosphatase 2A. Plant Cell 23:1494-1511. https://doi.org/10.1105/tpc.110.074278

36. Lievens L, Pollier J, Goossens A, Beyaert R, Staal J (2017) Abscisic acid as pathogen effector and immune regulator. Front Plant Sci 8:. https://doi.org/10.3389/fpls.2017.00587

37. López A, Ramírez V, García-Andrade J, Flors V, Vera P (2011) The RNA silencing enzyme RNA polymerase $\mathrm{V}$ is required for plant immunity. PLoS Genet 7:.

https://doi.org/10.1371/journal.pgen.1002434

38. Lumbreras V, Campos N, Boronat A (1995) The use of an alternative promoter in the Arabidopsis thaliana HMG1 gene generates an mRNA that encodes a novel 3-hydroxy-3-methylglutaryl coenzyme A reductase isoform with an extended $\mathrm{N}$-terminal region. Plant $\mathrm{J} 8: 541-549$. https://doi.org/10.1046/j.1365-313X.1995.8040541.x

39. Marasas WFO, Nelson PE, Toussoun TA (1984) Toxigenic Fusarium species. Identity and Mycotoxicology. Pennsylvania State University

40. McMullen M, Jones R, Gallenberg D (1997) Scab of wheat and barley: a re-emerging disease of devastating impact. Plant Dis 81(12):1340-1348

41. MacMillan J (2001) Occurrence of gibberellins in vascular plants, fungi, and bacteria. J Plant Growth Regul 20:387-442. https://doi.org/10.1007/s003440010038

42. Qi PF, Balcerzak M, Rocheleau H, Leung W, Wei YM, Zheng YL, Ouellet T (2016) Jasmonic acid and abscisic acid play important roles in host-pathogen interaction between Fusarium graminearum and 
wheat during the early stages of fusarium head blight. Physiol Mol Plant Pathol 93:39-48. https://doi.org/10.1016/j.pmpp.2015.12.004

43. Roy AK (1973) Ear blight and scab of wheat in Arunachal Pradesh. Curr Sci 43:162

44. Rodríguez-Concepción M, Campos N, Ferrer A, Boronat A (2013) Biosynthesis of isoprenoid precursors in arabidopsis. In: Isoprenoid Synthesis in Plants and Microorganisms: New Concepts and Experimental Approaches. pp 439-456

45. Saharan MS (2020) Current status of resistant source to Fusarium head blight disease of wheat: a review. Indian Phytopathology 73(1):3-9. DOI:10.1007/s42360-019-00186-x

46. Salvador-Guirao R, Baldrich P, Weigel D, RubioSo BS (2018) The microRNA miR773 is involved in the arabidopsis immune response to fungal pathogens. Mol Plant-Microbe Interact 31:249-259. https://doi.org/10.1094/MPMI-05-17-0108-R

47. Seo HS, Song JT, Cheong JJ, Lee YH, Lee YW, Hwang I, Lee JS, Choi Y, Do (2001) Jasmonic acid carboxyl methyltransferase: A key enzyme for jasmonate-regulated plant responses. Proc Natl Acad Sci U S A 98:4788-4793. https://doi.org/10.1073/pnas.081557298

48. Siewers V, Smedsgaard J, Tudzynski P (2004) The P450 monooxygenase BcABA1 is essential for abscisic acid biosynthesis in Botrytis cinerea. Appl Environ Microbiol 70:3868-3876. https://doi.org/10.1128/AEM.70.7.3868-3876.2004

49. Siewers V, Kokkelink L, Smedsgaard J, Tudzynski P (2006) Identification of an abscisic acid gene cluster in the grey mold Botrytis cinerea. Appl Environ Microbiol 72:4619-4626. https://doi.org/10.1128/AEM.02919-05

50. Simon SA, Meyers BC (2011) Small RNA-mediated epigenetic modifications in plants. Curr Opin Plant Biol 14:148-155

51. Stermer BA, Bianchini GM, Korth KL (1994) Regulation of HMG-CoA reductase activity in plants. J Lipid Res 35:1133-1140

52. Su C, Yang X, Gao S, Tang Y, Zhao C, Li L (2014) Genomics Identi fi cation and characterization of a subset of microRNAs in wheat (Triticum aestivum L.). Genomics 103:298-307. https://doi.org/10.1016/j.ygeno.2014.03.002

53. Sun F, Guo G, Du J, Guo W, Peng H, Ni Z, Sun Q, Yao Y (2014) Whole-genome discovery of miRNAs and their targets in wheat (Triticum aestivum L.). BMC Plant Biol 14:142. https://doi.org/10.1186/1471-2229-14-142

54. Tanaka N, Matsuoka M, Kitano H, Asano T, Kaku H, Komatsu S (2006) gid1, a gibberellin-insensitive dwarf mutant, shows altered regulation of probenazole-inducible protein (PBZ1) in response to cold stress and pathogen attack. Plant Cell Environ 29:619-631. https://doi.org/10.1111/j.13653040.2005.01441.x

55. Tian T, Liu Y, Yan H, You Q, Yi X, Du Z, Xu W, Su Z (2017) AgriGo v2.0: A GO analysis toolkit for the agricultural community, 2017 update. Nucleic Acids Res 45:W122-W129. https://doi.org/10.1093/nar/gkx382 
56. Trusov Y, Sewelam N, Rookes JE, Kunkel M, Nowak E, Schenk PM, Botella JR (2009) Heterotrimeric G proteins-mediated resistance to necrotrophic pathogens includes mechanisms independent of salicylic acid-, jasmonic acid/ethylene- and abscisic acid-mediated defense signaling. Plant J 58:6981. https://doi.org/10.1111/j.1365-313X.2008.03755.x

57. Ulferts S, Delventhal R, Splivallo R, Karlovsky P, Schaffrath U (2015) Abscisic acid negatively interferes with basal defence of barley against Magnaporthe oryzae. BMC Plant Biol 15. https://doi.org/10.1186/s12870-014-0409-x

58. Verhoeven KJF, Jansen JJ, van Dijk PJ, Biere A (2010) Stress-induced DNA methylation changes and their heritability in asexual dandelions. New Phytol 185:1108-1118. https://doi.org/10.1111/j.14698137.2009.03121.x

59. Viggiano L, de Pinto MC (2017) Dynamic DNA Methylation Patterns in Stress Response. pp 281-302

60. Wu F, Guo Q, Zhang W, Jin W (2014) Identification and Analysis of Powdery Mildew-Responsive miRNAs in Wheat. J Phytopathol n/a-n/a. https://doi.org/10.1111/.jph.12315

61. Xu R, Song F, Zheng Z (2006) OsBISAMT1, a gene encoding S-adenosyl-L-methionine:salicylic acid carboxyl methyltransferase, is differentially expressed in rice defense responses. Mol Biol Rep 33:223-231. https://doi.org/10.1007/s11033-005-4823-x

62. Yabuta T, Sumiki Y, Fukunaga K, Horiuchi M (1950) The biochemistry of bakanae fungus. Part 21 22. Nippon NÅgeikagaku Kaishi 24:395-397. https://doi.org/10.1271/nogeikagaku1924.24.395

63. Yang Q, He Y, Kabahuma M, Chaya T, Kelly A, Borrego E, Bian Y, El Kasmi F, Yang L, Teixeira P, Kolkman J, Nelson R, Kolomiets M, Dangl JL, Wisser R, Caplan J, Li X, Lauter N, Balint-Kurti P (2017) A gene encoding maize caffeoyl-CoA O-methyltransferase confers quantitative resistance to multiple pathogens. Nat Genet 49:1364-1372. https://doi.org/10.1038/ng.3919

64. Yao Y, Guo G, Ni Z, Sunkar R, Du J, Zhu J-K, Sun Q (2007) Cloning and characterization of microRNAs from wheat (Triticum aestivum L.). Genome Biol 8:R96. https://doi.org/10.1186/gb-2007-8-6-r96

65. Yoshioka H, Miyabe M, Hayakawa Y, Doke N (1996) Expression of genes for phenylalanine ammonialyase and 3-hydroxy-3-methylglutaryl CoA reductase in aged potato tubers infected with Phytophthora infestans. Plant Cell Physiol 37:81-90. https://doi.org/10.1093/oxfordjournals.pcp.a028917

66. Zhang M, Kimatu JN, Xu K, Liu B (2010) DNA cytosine methylation in plant development. J Genet Genomics 37:1-12

\section{Figures}



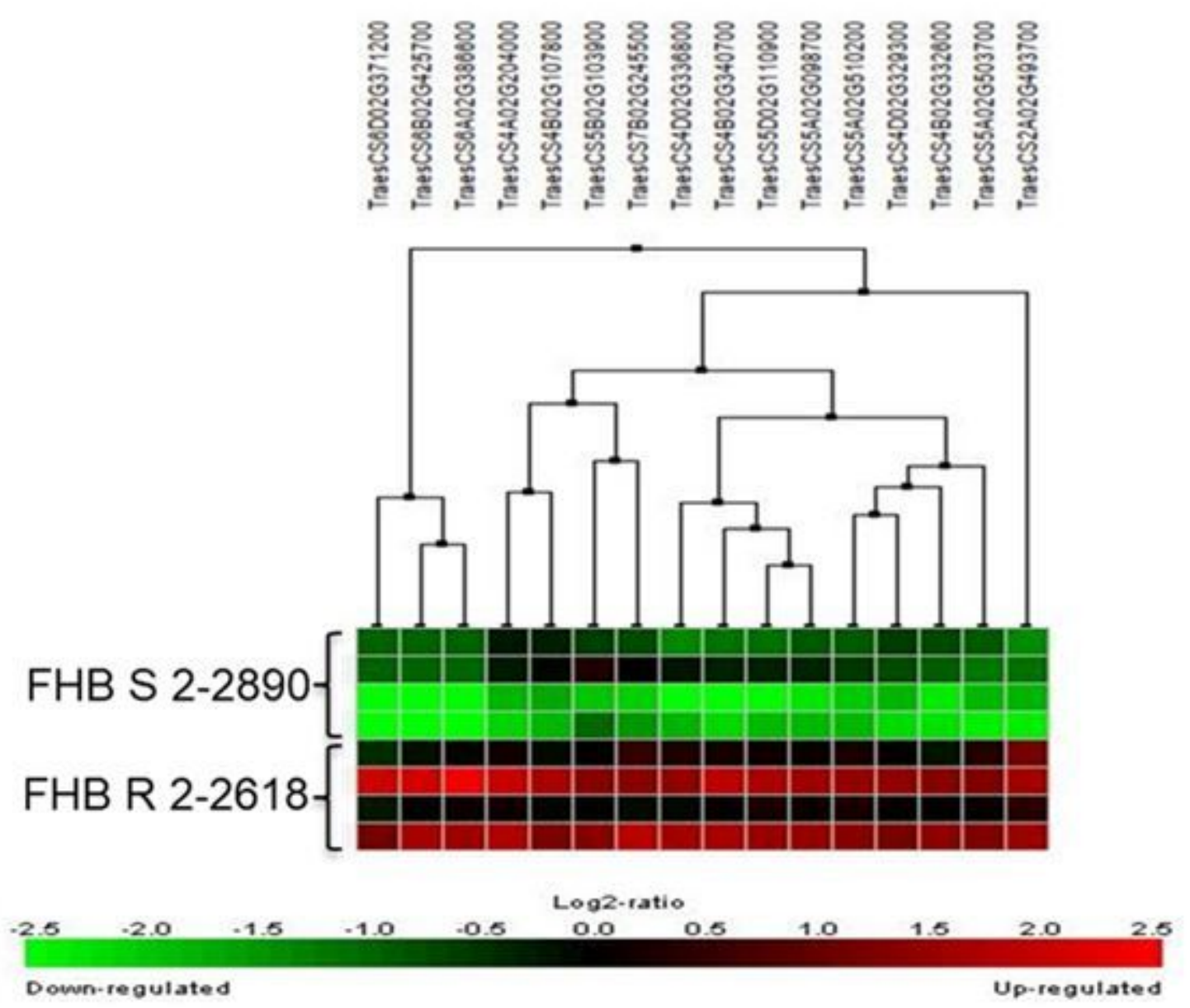

Figure 1

The methylation-related genes down-regulated in a susceptible line, 2-2890 and the corresponding genes up-regulated in a resistant line 2-2618 


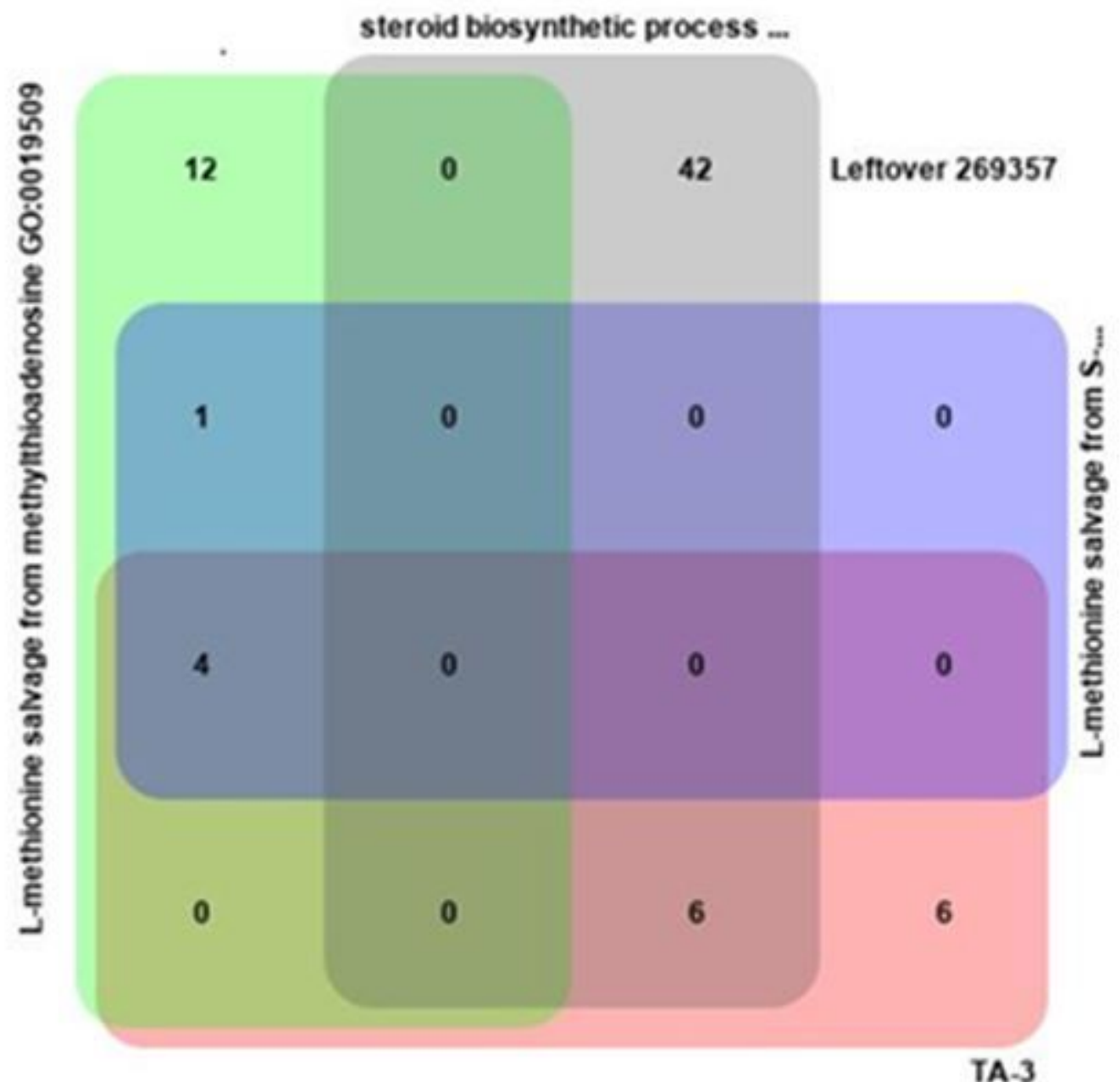

Figure 2

Gene Ontology (GO) analysis of methylation-related genes. The enriched GO terms were L-methionine salvage from methylthioadenosine and S-adenosylmethionine and steroid biosynthesis 


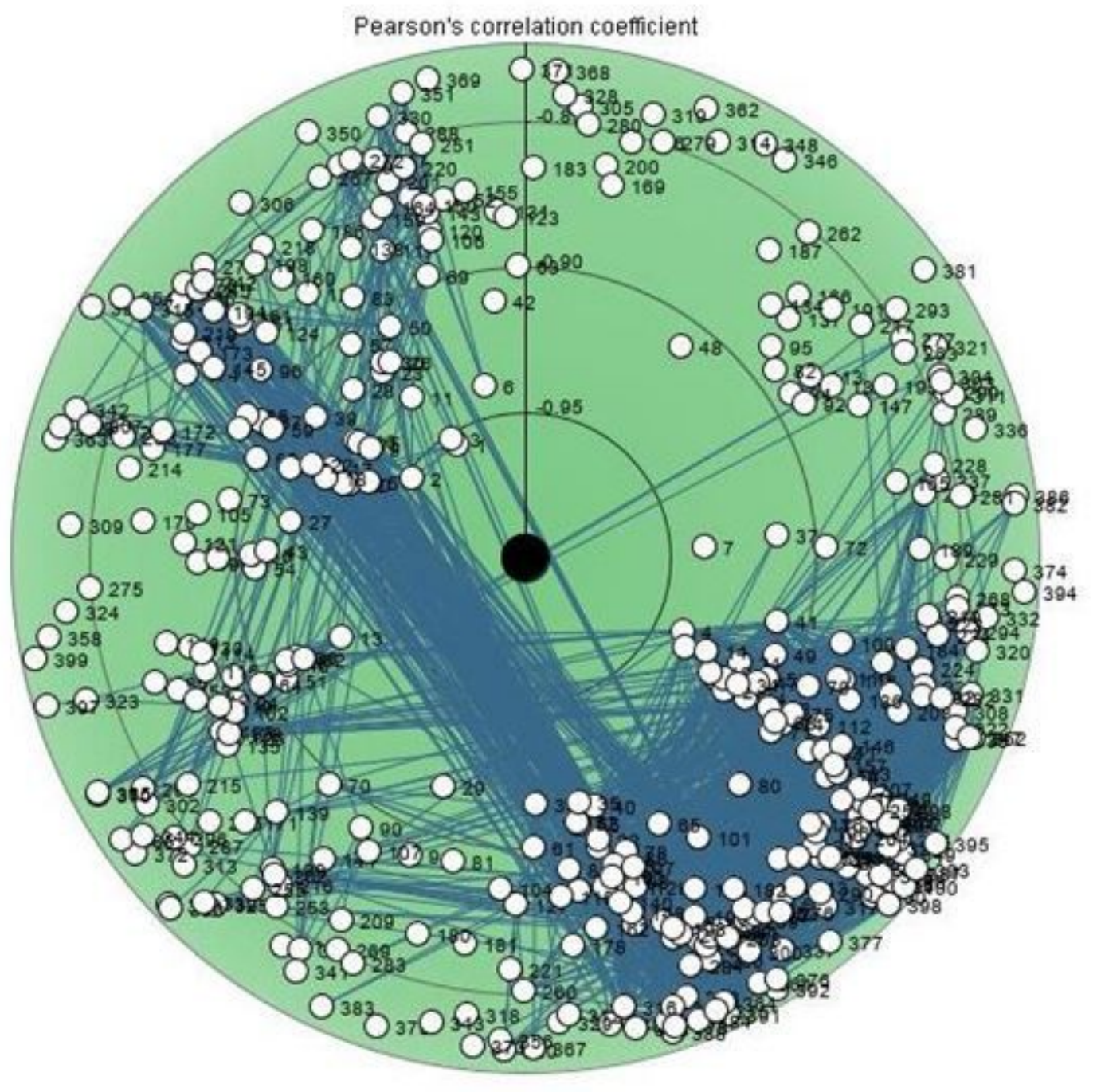

Show only genes with correlation above: -0.828

Connect genes with mutual correlation at least: 0.944

\section{Figure 3}

Differential co-expression analysis of methylation-related genes. The methionine S-methyl-transferase gene (MSM; TraesCS1A02G013800) was taken as the lead gene (black circle) and 218 methylationrelated genes were added (white circles) 


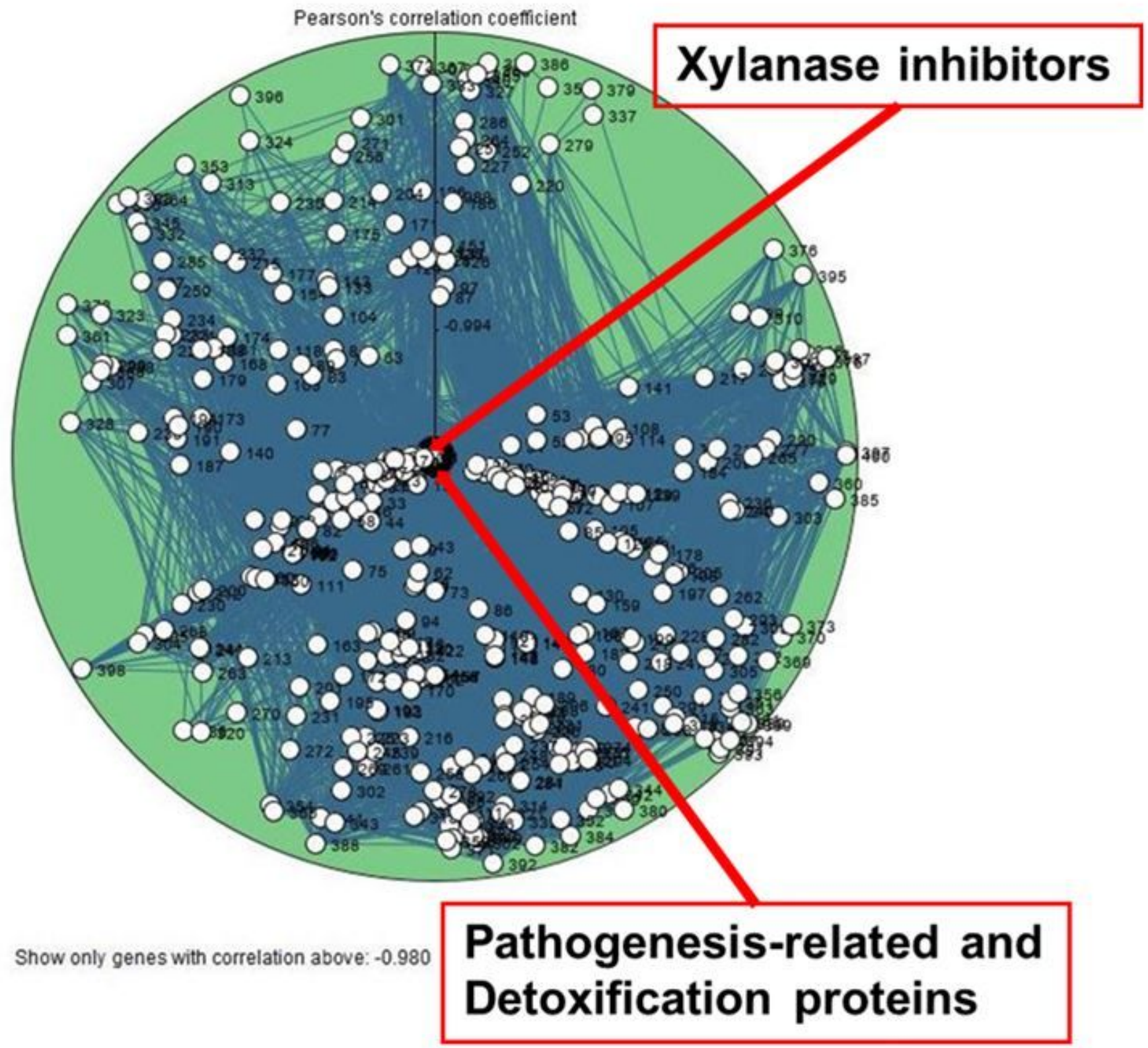

Connect genes with mutual correlation at least 0.992

Figure 4

Differential co-expression analysis of 3-hydroxy-3-methyl-glutaryl coenzyme A reductase (HMGCR). The HMGCR was found to be negatively correlated $(-1.00)$ to genes encoding pathogenesis-related and detoxification proteins and xylanase inhibitors 


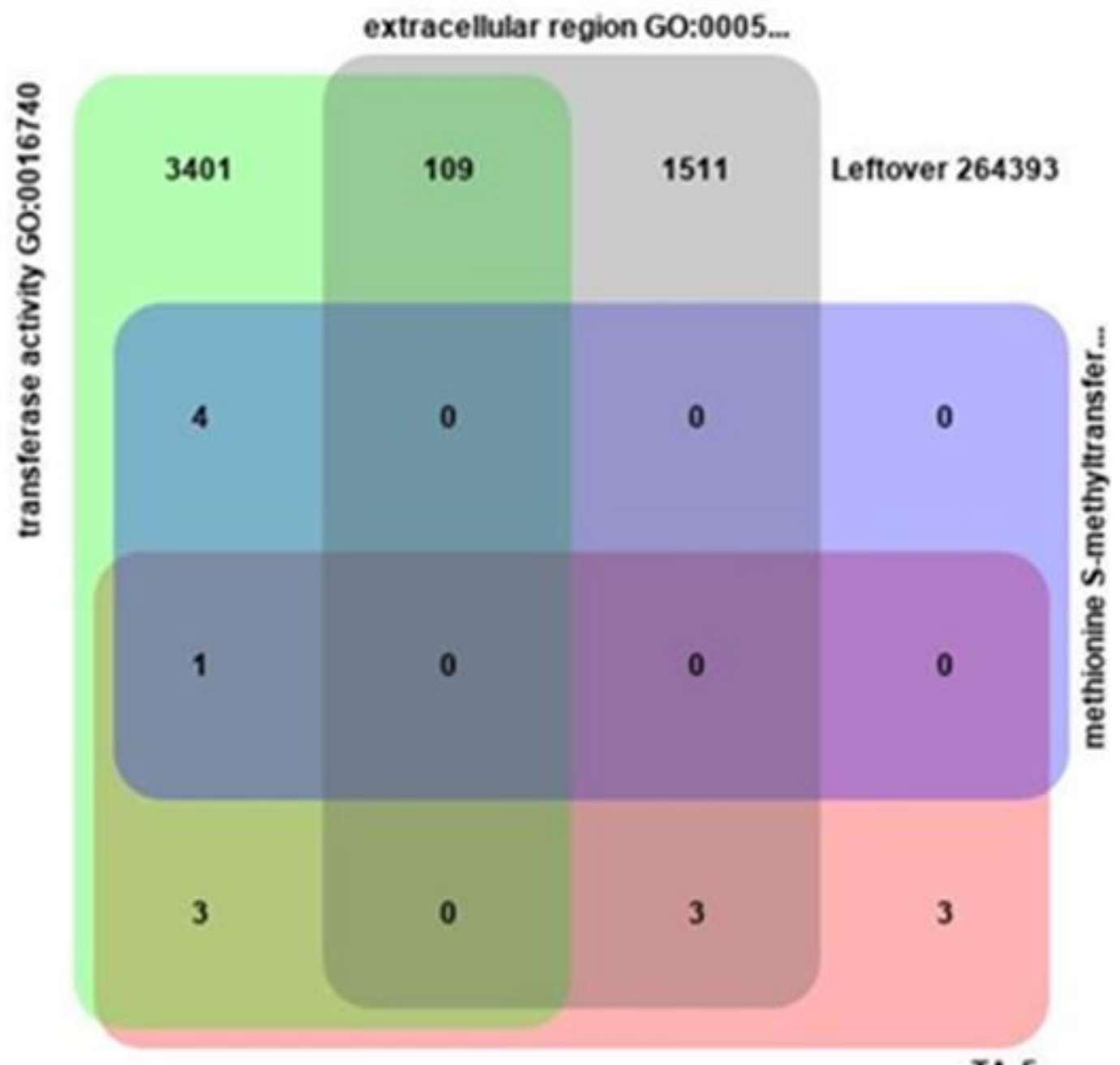

TA-5

\section{Figure 5}

Gene ontology enrichment analysis of the selected negatively correlated genes. GO analysis associated these genes, encoding pathogenesis-related and detoxification proteins as well as xylanase inhibitors, with methionine S-methyl transferase activity 
Dataset 22 samples from data selection: TA_mRALSEQWWEAT_GL

TraesCS1A02G013800 against TraesCS5A02G269300 on selection: TA-4

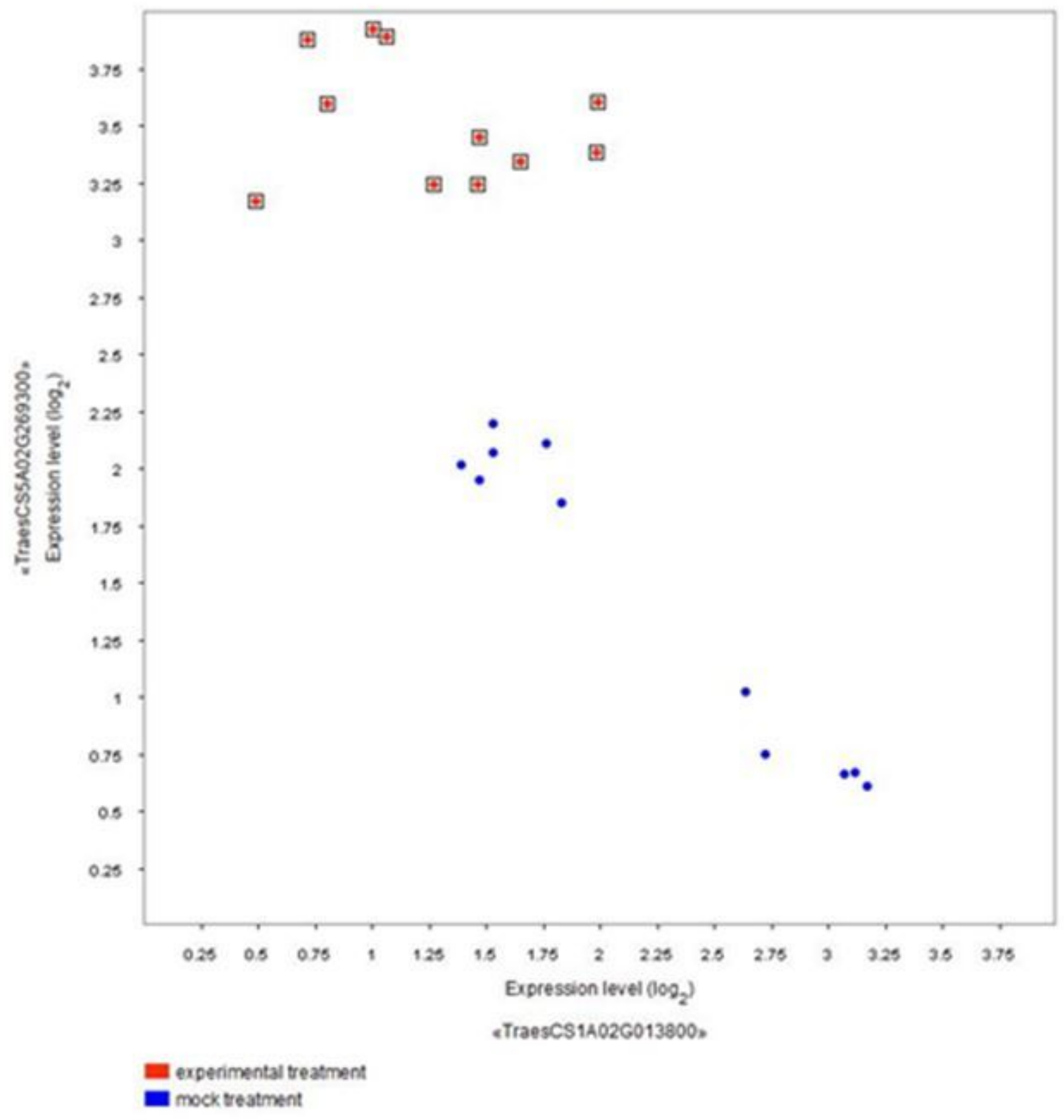

Figure 6

2 - Gene plot analysis of 3-hydroxy-3-methyl-glutaryl coenzyme A reductase (HMGCR) and methionine Smethyl-transferase (MSM) genes of an FHB S line, 2-2890. HMGCR was expressed in pathogen inoculated; whereas, MSM was expressed in mock-inoculated plants 


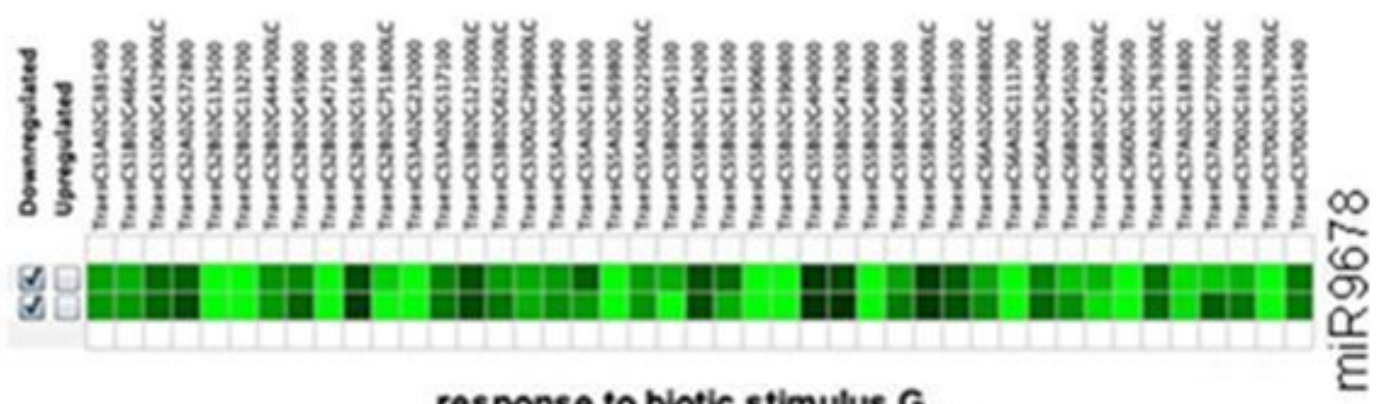

a

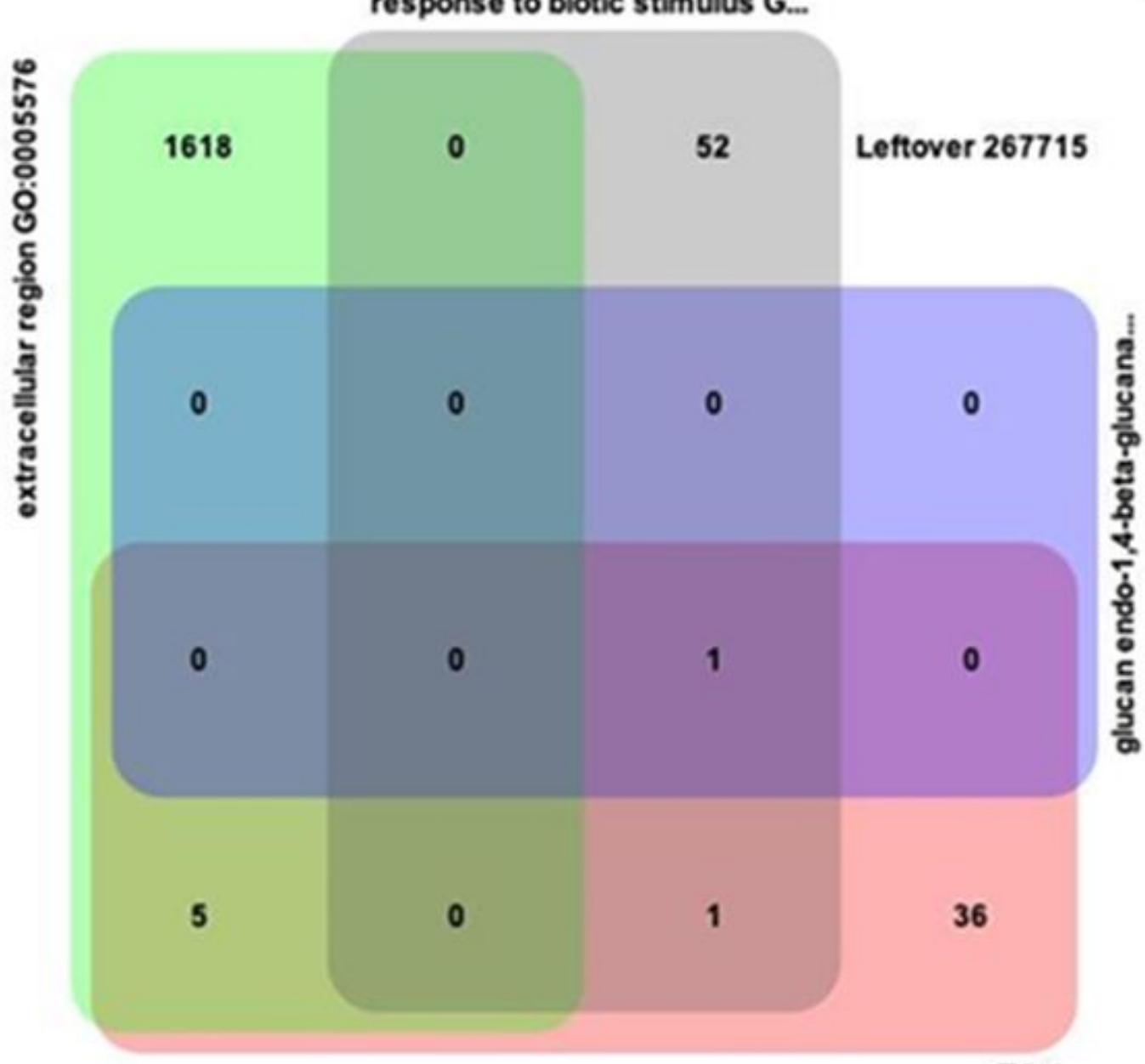

b

TA-1

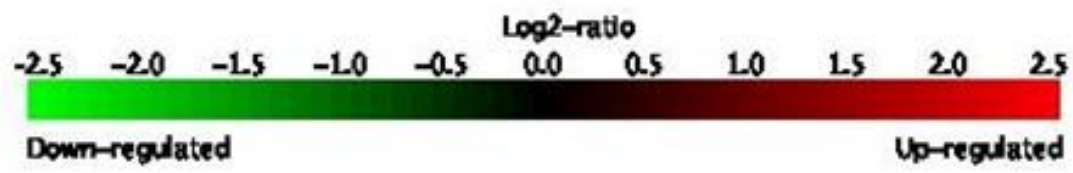

Figure 7

Effects of a miRNA on methylation-related genes and its gene ontology (GO) analysis. (a) miR9678 downregulating 43 methylation-related genes. (b) GO terms associated with 43 down-regulated methylationrelated genes 

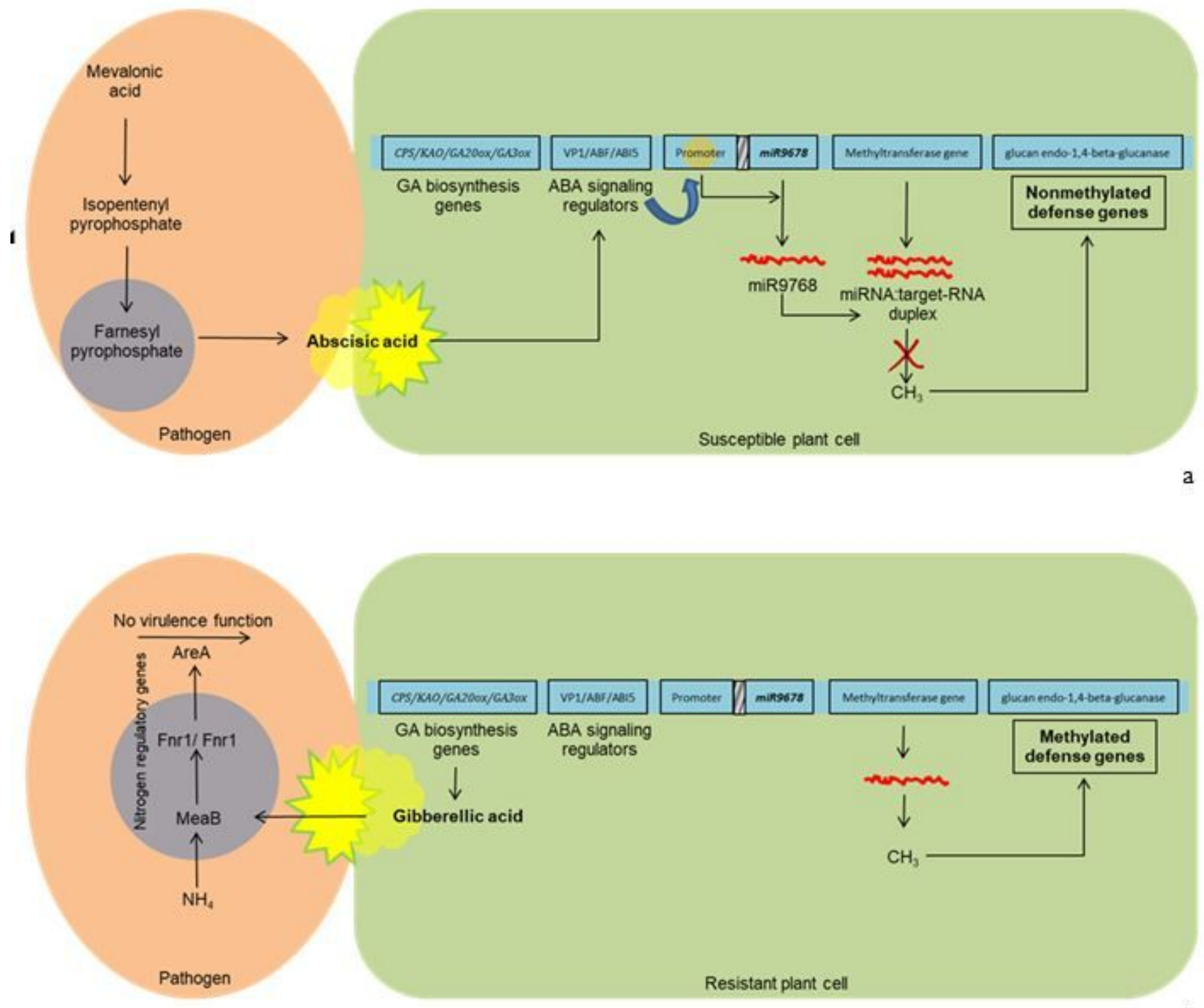

\section{Figure 8}

Hypothetical model of ABA-miR9678-GA mechanism that affects defence responses in plants against invading pathogens. (a) In susceptible plants binding of $A B A$ signalling regulators to a promoter of miR9678 increases its expression and downregulates its target methyltransferase genes resulting in nonmethylation of defence genes. (b) In resistant plants increased levels of GA misregulate the expression of pathogen's metabolic genes resulting in enhanced disease resistance 